\title{
ALTERNATIVE COMBINATIONS OF DETERMINANTS CREATING FINANCIAL STRATEGY. THE CASE OF POLISH UNIVERSITY SPIN-OFF COMPANIES
}

The aim of this paper is to demonstrate the existence of alternative sets of determinants creating financial strategy of university spin-off companies in Polish conditions. To develop these topics Qualitative Comparative Analysis (QCA), an inductive analytic technique relying on set theory, was adopted. In this study, fifty-three selected Polish university spin-off companies (USOs) were characterized. The paper makes reference to the entrepreneurial finance literature which identifies some factors that influence the process of obtaining funds for new technology-based firms, like USOs. These factors can influence the possibility of financing positively or negatively and, as indicated in the literature including the entrepreneurial figure, the nature of the project, the financial scenario, and the market characteristics. In the paper, for each of these, deep insights into their relation to finance were provided.

The following questions were asked: what added value can be provided by so-called informed capital, that is, a supply of money by a subject capable of evaluating innovative processes and technological issues and supporting the entrepreneur in running the business? And what are the roles of the two main types of capital sources, debt and equity, in the Polish context? What is important, therefore, "Do firms, especially small, young firms, get enough money to fund viable projects? And if not, what, if anything, should be done about it?" These questions are beguilingly simple to ask, and, needless to say, much less easy for economists to answer. The focus of this paper is, therefore, the analysis of the variables that determine the access to capital by USOs. This problem is highly relevant as Poland suffers from a significant delay in financial maturity compared to the United Kingdom and the United States, as well as to its closer nations, like France and Germany. The objective of this paper is to demonstrate the existence of alternative sets of determinants, creating the financial strategy of USOs. The study of the configuration of attributes was carried out using Boolean algebra - a notation system enabling the algebraic processing of logic statements. This analysis identified four alternative causal combinations associated with the entrepreneurial figure, the nature of the project, the presence of particular financial constraints and guarantees, and the market characteristics; one of them leads to $\mathrm{VC}$ funding, the next alternative two to debt financed by banks, and the last ones to government grants financing outcomes.

Keywords: financial strategy; set-theoretic approach, Qualitative Comparative Analysis, spin-offs

DOI: $10.15611 /$ aoe.2020.1.15

\footnotetext{
* Silesian University of Technology, Gliwice, ORCID: 0000-0001-5204-1259.
} 


\section{INTRODUCTION}

One of the major sources of innovation in the economy are scientific research results, which are transformed into solutions useful in human life and in the activity of enterprises. The process of the commercialization of new technologies and knowledge can be regarded as a process of creating a new value based on the scientific knowledge. The effects of commercialization process' projects, on the other hand, are visible at every turn in products and services utilized in everyday life. The commerciallization process itself is not, however, an easy thing, and in this case success does not occur automatically. Instead, it is a result of hard work and ingenuity, and is usually accompanied by a high risk of failure. In addition, projects of this type usually require major financial resources for research and development and implementation processes or marketing campaigns, aimed at making potential customers acquainted with the new solution/ product. Such characteristics of commercialization projects do not make the acquisition of appropriate resources in the financial market an easy task. Usually it is necessary to consider the possibility of using instruments other than those utilized within the 'regular' capital investment projects.

Many enterprises are involved in the development and implementation of new technological solutions in Poland. Among those, increasing interest is being generated by those performing the technology transfer, together with the transfer of know-how stored in the minds of researchers, i.e. enterprises/firms set up by representatives of academia, professors, $\mathrm{PhDs}$, and even students, so-called university spin-off companies (USOs). USOs are a subset of entrepreneurial companies. They can be defined (Callan, 2001; Lockett, Wright, 2005; Wright et al., 2006; Pattnaik et al. 2014, Kwiotkowska 2015, Jung et al., 2018) as: any new company which licenses or otherwise makes use of intellectual property from a university or public research institute, or any new company in which a university or national laboratory has made an equity investment, or any new company directly established by a public research institution. USOs came into being in the Polish economy along with the economic transformation in the early 1990s. Admittedly, however, this phenomenon is still relatively little developed. Nevertheless, recent years in particular have seen an increase in interest in this area on the part of the research environment. USOs have also found their place as an element of economic policy in a broad sense - their creation can be promoted and, to some extent, supported in the framework of national, regional and operational programmes. The Act on higher education of 2005 
placed academic entrepreneurship within the basic scope of activity of universities in Poland. Apart from conducting scientific research and educating students, they are also obliged to collaborate with their economic environment, in particular by selling or making available free of charge the results of research and development work to entrepreneurs, and to disseminate the idea of entrepreneurship in academia in the form of organizationally and financially distinguished business activity, which can be directly referred to the creation of a USO. In Poland's case, the number of USOs established since the beginning of the 1990s is estimated at about 100 .

In recent years the increase in the awareness level of politicians, public administration, the authorities of many Poland's universities, as well as the academia itself, has resulted in the creation of conditions that are increasingly friendly to the real flourishing of entrepreneurship based on knowledge, expertise and technologies developed in Polish universities. This is favoured by co-financed, often from public resources, technology transfer centres, technology incubators and technological parks, venture capital funds and projects disseminating the knowledge of technology transfer, carried out by entities specializing in this matter. Academic entrepreneurship in Poland is also supported by the amendments of regulations proposed in the assumptions for the higher education reform, which compel universities to define clear rules of managing intellectual property, conflicts of interests and activities within USOs. While the growth of USOs requires primarily, in addition to ideas and their effective protection, also the courage to take the risk of market activity and financial resources.

On the other hand, however, it should be underlined that in Poland, the industrial and cultural context scarcely seems to stimulate the development of entrepreneurial activities with a high knowledge content; Poland is a late entrant in the R\&D race. The gap between Poland and other advanced economies seems even wider when the amount of invested financial resources, the number of committed staff, and the results of innovation are concerned. In addition to the inadequate investment in R\&D, Poland also has to contend with the failure to enhance the existing research activity by converting innovation and discovery into marketable products and processes. What is more, new technology-based firms are commonly known to be resource constrained, and need to obtain external financing in order to pursue their opportunities (Shane, Cable, 2002). The situation for USOs seems aggravated; USOs in Europe report their ability to obtain financing as the most dominant factor impeding USO creation (Wright et al., 2006). 
Moreover, a vast majority of enterprises in the EU are micro, small and medium-sized firms (99.8\%). An identical situation occurs in Poland, where among 2.01 million firms, the SME sector entities make up a definite majority (99.8\%), while in Poland, compared to the EU, this sector is more dominated by micro-firms, whose share of the total number of enterprises (96.2\%) exceeds the European average (91.8\%) (PARP - the Polish Entrepreneurship Development Agency, 2018). Importantly, even though micro-firms with fewer than 10 employees, which include USOs, have huge needs for resources, the Polish financial market is still immature - on the one hand because of the low availability of venture capital and operators, and on the other because of the inability of the banking system to undertake specific evaluations of the quality of entrepreneurial activities. Poland's capital market for innovation is booming due to the new initiative of banking and the growing sensitivity to venture capital and other private institutions. This sort of capital can add support to technological and entrepreneurial development. Thus, over the past few years, this fact has resulted in Poland in the emergence of firms which were able to finance their fast growth at various stages of their activities. Among such undertakings, one can include Genomed, a company which offers the services of making a synthesis of oligonucleotides and DNA sequencing used in medical molecular diagnostics, industry, science and forensic medicine. The enterprise was established in 2007, and in January 2008 the company managed to acquire an investor in the form of the seed capital fund of MCI BioVentures (belonging to the MCI Management stock exchange group), who invested 900000 PLN (about 215000 EUR) in the company in the first tranche, and the whole investment amounted to 1800000 PLN (about 429000 EUR) for $47 \%$ of shares. A similar investment history is shared by Stem Cells Spin S.A., who is the Wroclaw Medical University's USO. The company was set up in 2009, and in the same year it acquired a venture capital investment from the fund of BIO-MED Capital S.A. (the shares of Privilege Capital Management S.A. were transferred to BIO-MED Capital S.A.).

More specifically, as financing sources commonly available in the Polish financial market, are used also in the framework of various stages of technology and knowledge commercialization projects, the following can be indicated: bank credit, especially in the form of an investment credit, but also its other forms; lease; loans from loan funds, which are available to projects carried out by small and medium-size enterprises; guarantees available from credit guarantee funds; capital investments from venture capital funds; and subsidies for innovative projects available, e.g. in the 
framework of national, regional operational programmes like Smart Growth Operational Programme 2014-2020.

The objectives of this paper are to:

- deepen the knowledge of the relationship between finance and entrepreneurship by systematically reviewing the large related literature;

- demonstrate the existence of alternative sets of determinants, creating the financial strategy of USOs.

Hence, for this research, the following questions were asked: what added value can be provided by so-called informed capital (Schäfer et al., 2003), that is a supply of money by a subject capable of evaluating innovative processes and technological issues and supporting the entrepreneur in running the business? And what are the roles of the two main types of capital sources, debt and equity, in the Polish context?

What is important, therefore, "Do firms, especially small, young firms, get enough money to fund viable projects? And if not, what, if anything, should be done about it? These questions are beguilingly simple to ask, and, needless to say, much less easy for economists to answer" (Cressy, 2002). The focus of this paper is, therefore, the analysis of the variables that determine the access to capital by USOs. This problem is very relevant, as Poland suffers from a significant delay in financial maturity compared to the United Kingdom and the United States, and to its closer nations, like France and Germany.

To develop these topics, Qualitative Comparative Analysis (QCA) was adopted - an inductive analytic technique, relying on set theory (Ragin, 1987). It is a useful tool to represent and analyze inaccurate and qualitative information (which is difficult to define through a deterministic method) and above all for structuring complex phenomena. Recent advances in set theory have led researchers to develop a range of approaches to undertaking QCA (see Ragin, 2000). The fuzzy set QCA is distinguished from the traditional crisp-set QCA by the nature of the variables under consideration (Ragin, 2000). While crisp-set QCA forces the dichotomization of conditions, fsQCA permits the scaling of membership to sets of independent and dependent variables, by allocating a score between 0 and 1 (Ragin, 2008). In this way, fsQCA allows researchers to take account of differences in the strength of organizational and social phenomena under their analyses.

In this study, fsQCA is used to identify and select alternative combinations of determinants creating financial strategy of USOs in Polish conditions. In theoretical and empirical terms, it is a novel context in which to use fsQCA. What is more, in utilizing fsQCA in this setting, it is possible 
to illustrate the value of this nascent approach, whilst also addressing an important gap in the current academic literature on the management of entrepreneurial organizations.

This work is the first step in a broader course that could lead to the realization of a meticulous model to be used as a synthetic scheme to study business cases accurately, or a construct for empirical verification, through a survey with quantitative analysis of the relevance of detected determinants and a predictive model to support entrepreneurs. The remainder of this paper is structured as follows. First, a brief literature review of the relevant theoretical and empirical literature was provided. Next, the method and data were described and the results of empirical analyses were presented. The concluding section discusses the implications of findings for the creation of the financial strategy of USOs.

\section{LITERATURE REVIEW}

Entrepreneurial finance literature identifies some factors that influence the process of obtaining funds for new technology-based firms. These factors can influence the possibility of financing positively or negatively (Minola, Giorgino, 2008). The entrepreneurial figure, that is, the founder/manager or the management team of a new business, is the first and most relevant factor. Ensley, Carland, and Carland (1998) state that individuals have to fulfil three criteria in order to be considered members of the entrepreneurial team: they (1) have jointly established a firm; (2) have a financial interest; and (3) have a direct influence on the strategic choice of the firm. Other researchers have made the equity stake condition stricter and have imposed a minimum equity stake before one can be considered a member of the entrepreneurial team (Ucbasaran et al., 2003). The manager's or team's education and track record in the field of the new project for which funds are sought are positively correlated with the probability of obtaining capital (Colombo, Grilli, 2005). What is more, the level of individual entrepreneurial orientation is the result of a number of factors such as personal wealth, experience, judgment, intelligence, and education. These factors also affect the choice of the financial strategy (Minola, Giorgino, 2008). For new ventures, the entrepreneur(s) is/are the most critical, if not the only, human capital present in the firm (Van de Ven et al., 1984; Klotz et al., 2013). The size of the team and their experience and education are of key importance (Roberts, 1991; Shane, Stuart, 2002), while the knowledge of the sector and proper management enable appropriate activities and changes to be implemented, 
which will adjust the firm to the environment and develop the market potential (Cohen, Levinthal, 1990).

It is well established in the literature (Colombo, Delmastro, 2002; Shane, 2004) that the founders of USOs usually have more formal education levels - owing to their academic origin (Siegel, Waldman, Link, 2003; Ndonzuau, Pirnay, Surlemont, 2002) - but fewer managerial skills (Shane, Khurana, 2003; Shane, 2004; Vohora, et al, 2004) than similar technology-based startups. Moreover, venture capitalists do not want to invest in USOs where the founding team consists only of researchers without business experience (Wright et al., 2007). Therefore, universities try to attract surrogate entrepreneurs to partner-up with the founders and present the proposal to a VC. If no surrogate entrepreneur is available, VCs might suggest looking for a manager and recruiting the manager as the condition of investing. This means that the deal only goes ahead if a manager can be recruited to complement the founding team (Minola, Giorgino, 2008).

On the other hand, Ortin-Angel and Vendrell-Herrero (2010) provide an analysis of the consequences of the differences between USOs and other technological start-ups in the presence of venture capitalists. They showed that the existing literature has analyzed the factors explaining the variability in the presence of venture capitalists within high-tech start-ups, but remains silent about the variability between university spin-offs and independent start-ups. To answer their question "Why do USOs attract more venture capitalists?" they used a questionnaire answered by a sample of 64 Spanish technological firms founded between 1993 and 2005, comprising 40 USOs and 24 high-tech independent start-ups. The authors found that, on average, USOs are more likely to have VCs than independent start-ups. In their sample this is explained by the greater presence of venture capitalists in those USOs whose founding team lack managerial skills. These results support the complementary assets view that academic entrepreneurs use VC investors as a means of gaining access to managerial skills (Ortin-Angel, Vendrell-Herrero, 2010).

Landier's (2002) perspective on the debt/equity dilemma focuses on the entrepreneur's personal risk aversion, represented by the 'stigma of failure,' which is proxied by the difference in wages if the venture were to succeed or fail. Entrepreneurs with a low stigma of failure run more aggressive businesses and are more likely to obtain equity finance (Minola, Giorgino, 2008).

Another issue is also the amount of money that the entrepreneur has invested into the new venture. Huyghebaert and Van de Gucht (2004) found that entrepreneurs who provide a credible quality signal through the amount 
of equity committed to their venture have a larger proportion of bank debt, which indicates that banks do take at least some information into account; the higher the capital committed by the entrepreneur, the higher the probability that external financing will be leveraged, as self-financing is viewed positively by banks and venture capitalists (Huyghebaert, Van de Gucht, 2004).

In turn, Shane (2004) asserted that problems with a higher degree of information asymmetries could arise at least for three different reasons: the lack of necessary scientific understanding for evaluating business proposals, the existence of bargaining problems between the entrepreneurs and investors, and the limited availability of collateral to minimize the investors' risks. Additionally, collateral, i.e. all the assets that a business can provide as a guarantee for a loan, is often the principal determinant for banks when providing finance (Chittenden et al., 1996). The situation is different for venture capitalists who consider information and intangible assets as guarantees. For technology-based and early-stage companies the problems related to the achievement of funding derive from the existence of not only information asymmetries, but also high levels of risk, and significant monitoring costs involved (Hall, 2002). Many have tried to verify the reliability of the general assumption in entrepreneurial finance that higher risk unambiguously means equity funding (Minola, Giorgino, 2008). For example, Schäfer et al. (2003), in a survey of more than 600 high-tech investments in Germany, found that there is no clear segmentation concerning funding sources with regard to different levels of risk. They show that risk is not a reliable basis from which to calculate the likelihood of a project being equity financed. On the other hand, Hellmann and Stiglitz (2000) suggest that high-risk and high-return entrepreneurs may choose debt: the success of the venture might leave them a bigger portion of the profit, which would have to be shared with an investor if they chose equity financing.

The next issue relates to technology. High tech is connected to high risk, which makes projects less attractive to banks, but, conversely, more attractive to venture capitalists (Audretsch, Lehmann, 2004). An interesting contribution comes from Ueda (2004), whose model considers information asymmetries as relevant drivers of the debt/equity dilemma. Ueda (2004) evidenced in the research that the choice between debt and equity depended especially on two elements: (1) the severity of the asymmetric information problem between the entrepreneur and the bank, and (2) how strongly intellectual property rights are protected. The low collateral value, high 
growth and high risk of the project all raise the cost of the asymmetric information and thereby drive the entrepreneur to finance through the venture capitalist. Stronger protection of intellectual property rights weakens the threat that the venture capitalist may expropriate the entrepreneur's project, and thereby encourages the entrepreneur to finance through the venture capitalist. This relationship has also been justified by other arguments. Hellmann and Puri (2000) suggest that in an environment with imperfect information on the quality of the projects, intellectual property protection is a way of signalling good projects and therefore attracts the attention of venture capitalists (Mann, Sager 2007).

USOs generally carry out business activities based on research that can be considered "pure," "basic" or "fundamental." Often, the final results of this type of research have no direct or immediate commercial benefits, or they require a long period of time to reach the market. Therefore, the presence of high risks and screening costs might discourage from involvement in this type of new ventures. A further element hampering the willingness to fund an USO is the uncertain distribution of intellectual property rights. The underlying idea is that investors would be more confident in financing USOs, if the relevant patents are directly assigned to the company rather than being assigned by the university in return for an equity share in the company (Munari, Toschi, 2010).

The venture capital literature (MacMillan et al, 1985; Wallmeroth et al, 2018) suggests that the ability of the research-based start-ups to obtain venture capital is strongly related to the size and international scope of its targeted market. Research conducted by Heirman and Clarysse (2004) confirm that international markets are attractive to investors, and start-ups need sufficient financial resources in order to penetrate a large and international market.

To sum up, based on the referred literature, as well as the interviews, together with continuous monitoring of other sources of information (such as newspapers, periodicals, websites), some assumptions about the Polish context can be formulated as a starting point for this work. Hence, on the entrepreneur's side there is a hierarchy of financing preferences derived from the fact that the entrepreneur wants to maintain control of his/her business without involving others, but this wish has to be traded off against the need for resources to grow the business and the disclosure when soliciting these will involve. Moreover, a start-up entrepreneur who has insufficient means is obliged to address external capital suppliers, according to the standard pecking order theory. This does not rule out the possibility of co-financing (which is an indication of quality for the investor). 
The literature poses some challenges, of which the most obvious is the lack of empirical analysis that allows the verification of a holistic view of financing USOs in the context of Poland. The objectives of this study are to spot the most important determinants in a firm's choice, to determine the nature of the correlation that these variables have with possible financing alternatives, and how they influence the fund-raising process.

To pursue these objectives, an empirical check is necessary at different levels of generalization and depth. This is quite a challenge as the orientation to debt (or risk capital) financing is a complex concept, both by definition and by nature. It is difficult to measure and appraise, as it relies on mostly subjective evaluations. It is also related to a broad and heterogeneous range of variables with specific and very different impacts. Moreover, orientation to a given financier never corresponds to an extreme solution (no business perfectly fits every criterion for access to debt); it mostly assumes intermediate values, rather than being skewed around one of the two alternatives - bank or venture capital (Minola and Giorgino, 2008).

In order to examine these issues, QCA was applied, which is discussed in the following section. The use of QCA is an original contribution to the wide range of determinant analysis in entrepreneurial finance. The achievement of the goal - to demonstrate the existence of alternative sets of determinants creating financial strategy, to help the entrepreneur wanting to start up a firm - will identify the best financer, banker, or venture capitalist for his/her project.

\section{METHOD AND DATA}

The type of research selected by the author was the multiple case study, in which several cases were studied simultaneously within a single research undertaking. A consequence of the selected research method was the nonrandom, intentional choice of a sample from USOs in Poland. The selection of enterprises was guided by the following criteria: the selected enterprises are relatively new, developing business ventures relying on the transfer of knowledge (as seen from the aspect of the transfer of intellectual assets, and not only technologies), set up by young persons, who are finalproject students, doctoral students, or academics. The research was conducted in the form of interviews with the founders or management representatives of fifty-three firms. After preliminary empirical research carried out on twenty-three entities, the research was continued at the turn of 
2016 and 2017, and the research sample was extended to fifty-three companies. In the course of the research it transpired that statistical data on the number of USOs entities in Poland had not been yet collected and classified. Thus, firstly CATI method was implemented to create an essential database of USO enterprises in Poland, which enabled to recognize 53 such subjects, and which were incorporated in the entirety of the sample.

Out of the 53 companies included in the sample, $60 \%$ were production and service enterprises and only $40 \%$ service ones. In addition, the surveyed group was composed of relatively new enterprises aged around 5 to 6 years. When taking into consideration the size of the discussed companies measured by the number of employees, micro and small enterprises accounted for $91 \%$ of the surveyed population and the remaining $9 \%$ were medium-size companies employing less than 250 employees. Furthermore, the researched group comprised entities which were classified in the high technology sector on the basis of the Eurostat method. The high technology sector, taking into account only its main field of activity, constituted $87 \%$ of the researched sample; $57 \%$ of mentioned companies performed in the Polish market, 13\% in the international/European market and around 30\% globally.

In the research, the triangulation procedure was utilized where the objectivism and realism of analyses were supported by the use of many different types of data (the internal documentation of enterprises examined and surveys with a standard list of questions), i.e. the triangulation of data, as well as the use of research methods such as an observation or a survey methodological triangulation. Information collected from the surveys and from other sources (e.g. the internal documentation of the enterprises, archival data, websites) was used for developing a database of cases studied as well as for carrying out an analytical procedure using Qualitative Comparative Analysis (QCA).

QCA is an inductive analytic technique relying on the set theory (Ragin, 1987). QCA facilitates the identification of multiple configurations of variables associated with the outcome of interest. It is an especially powerful approach, because it allows the analyst to derive configurations of key variables from case study evidence (including the grounded interpretations of quantitative data), which are associated with a focal outcome(s). In this study, fsQCA is used to identify alternative sets of determinants, creating a financial strategy of university spin-off companies based on the example of nineteen Polish ventures of this type. 


\section{VARIABLES}

To identify alternative combinations of determinants creating the financial strategy of USOs, fsQCA treats each possible configuration of key variables as a single case and identifies the necessary and sufficient causal conditions associated with each configuration. Through comparison, these cases are reduced to the minimum combinations of causal factors (e.g. connected with entrepreneur features such as management profile and skills and with market characteristics, like size and international scope) necessary for the outcome to occur (e.g. financed through venture capital). The analysis also uses consistency and coverage as two key parameters for assessing the fitting of the QCA results to the underlying data.

The analysis presented here is further structured to consider whether the factors responsible for the presence of a performance outcome are the same as those causing the absence of performance. The causes leading to the presence of an outcome of interest may be quite different from those leading to the absence of the outcome (see also Fiss, 2011). This is referred to as causal asymmetry (Ragin, 2008). It has been suggested that analyzing asymmetric set relations can extend knowledge gained from calculating the net effects of independent variables in linear models from a symmetric perspective, such as when using correlation and multiple regression-based approaches. Although the use of interaction terms in linear regression models can be used to test asymmetric hypotheses (Clark et al., 2006), the analysis of asymmetric set relations offers the potential for a much crisper assessment of the distinguishing characteristics associated with the presence or absence of a key outcome.

The literature review suggests that the first level of main determinants should be: the entrepreneurial figure; the nature of the project; the financial scenario; and the market characteristics. Dividing these into variables, with the support of the literature, the following was obtained:

- Management profile and skills: these refer to the entrepreneur and his/her team and measure their managerial skills and professional experience (Shane, Stuart, 2002; Cohen, Levinthal, 1990).

- Entrepreneurial orientation: a five-dimensional construct - autonomy, competitive aggressiveness, innovativeness, pro-activeness and risk-taking (Covin, Slevin, 1989; Miller, Friesen, 1980; Lumpkin, Dess, 1996), which was considered in particular from the aspect of the entrepreneur's tendency to entrepreneurial risk in terms of the concern this prompts about his/her career. 
- The nature of the project: in which it was considered how innovative and R\&D-related the project was, along with the issues associated with intellectual property protection and how significant information asymmetries could be (Audretsch, Lehmann, 2003). IP protection is measured as the sum of the current stock of licenses, patents and the firm's own brands (Shane, Stuart, 2002; Colombo, Grilli, Piva, 2006).

- Assets: these refer to every kind of guarantee the entrepreneur can provide (Chittenden et al., 1996).

- Market: the size of the targeted market, ranging from a niche to a large market, and the geographic coverage of the market, ranging from local focus to international/global (Heirman, Clarysse, 2004).

Therefore, based on the literature review, five attributes (management profile and skills, entrepreneurial orientation, the nature of the project, assets and market) were isolated, which provided a basis for the examination of USOs financial strategy.

To illustrate the performance outcomes, as measures of results, the presence of financing either by $\mathrm{VC}$ funds or a bank, as well as by any forms of government grants, were used. The result measures were encoded in a binary form, for example, to measure whether the firm is currently financed by venture capitalists (value one) or not (value zero), and similarly in the case of other sources of financing.

\section{DATA CODING}

The condition and outcome variables differed in their underlying forms and were recoded for inclusion in the analysis on a continuous scale from 0 to 1 (Ragin, 2008). Subsequently, a direct coding method was utilized to code individual case data points (as explained in Ragin, 2008). The direct method focuses on the three qualitative anchors that structure the degree of membership to the focus set. These are: (1) the threshold for full nonmembership; (2) the threshold for full membership and; (3) the cross-over point, where there is some ambiguity about membership.

Table 1 presents an overview of the membership scores for all of the conditions (management profile and skills, entrepreneurial orientation, the nature of the project, assets and market) and the outcomes (VC funding, debt financed by banks and government grants financing) for the fifty-three USOs considered in the analysis. Due to the fact that thirteen of the fifty-three investigated USOs had obtained funding in the form of loans accommodated by banks, while using financing in the form of government grants for $R \& D$ 


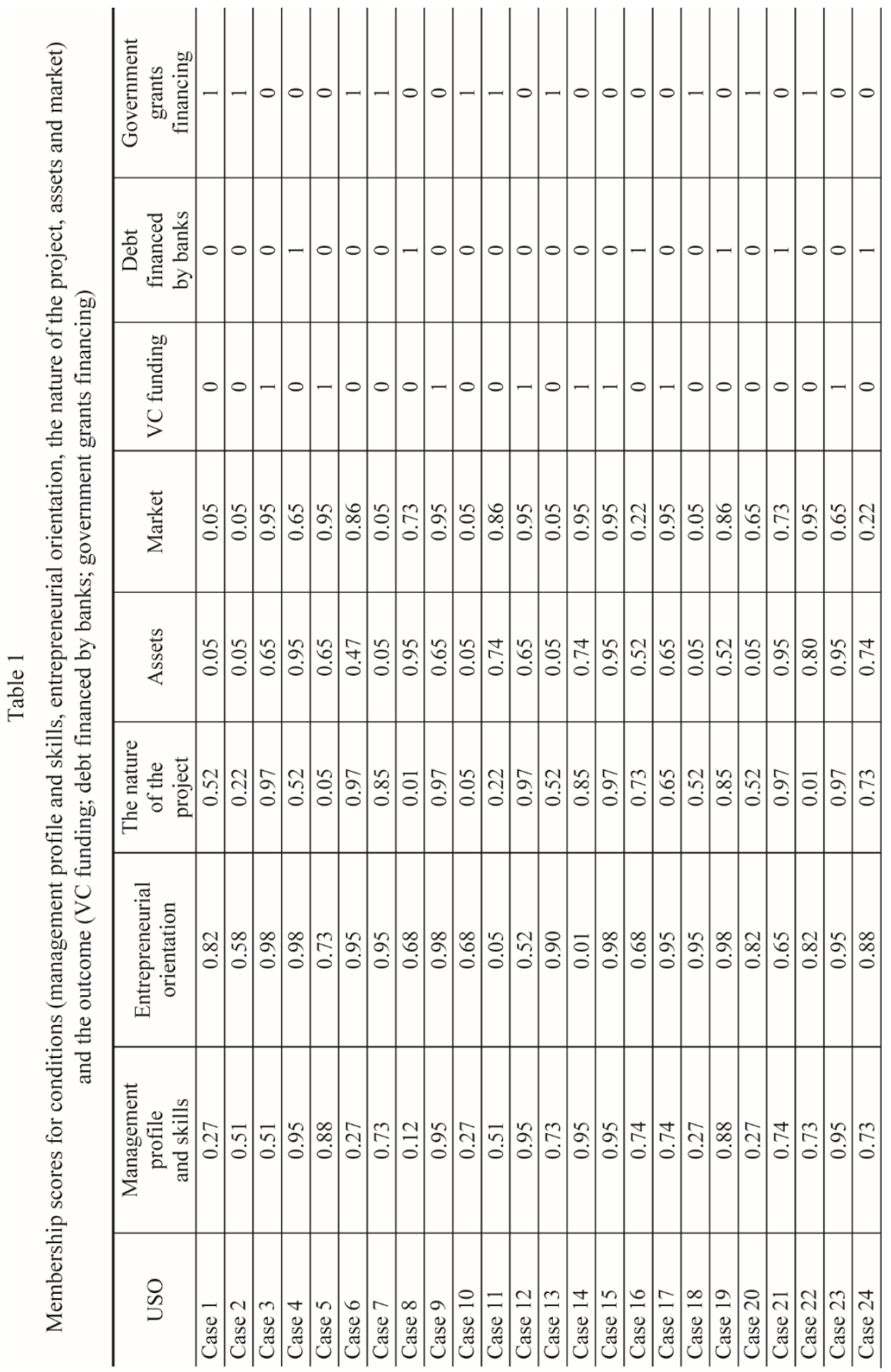




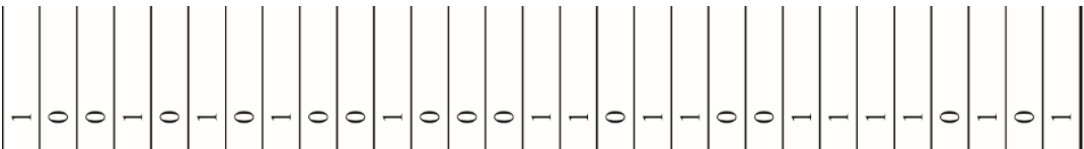

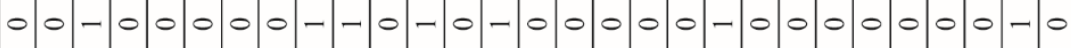

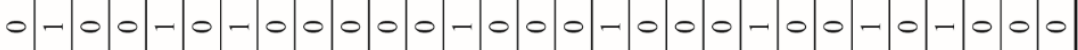

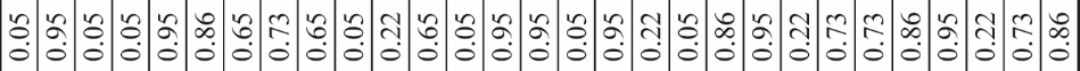

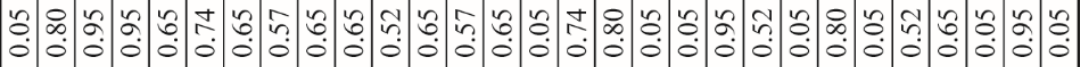

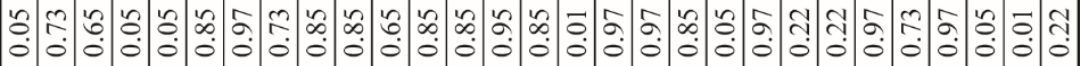

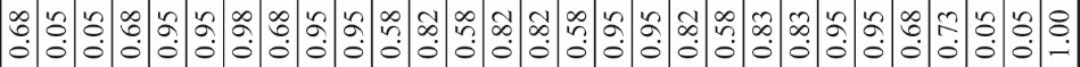

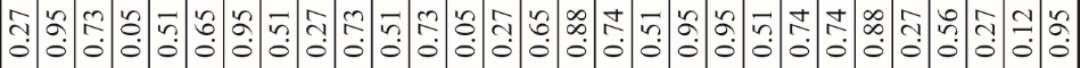

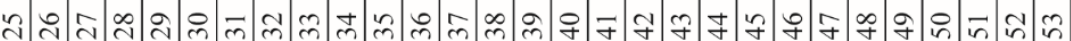

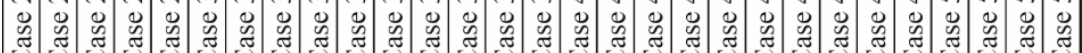


activity, the results coincided for the both financing sources, hence they were put in the same column.

The next analytical step is the consideration of causal combinations/ configurations of conditions and the outcome, here elucidated through truth tables. The truth table represents logically possible combinations of included conditions and is the key tool of set-theoretic analysis (Ragin, 1987), and it describes cases' diversity. However, this is often 'limited diversity', where all theoretically possible configurations are not represented in reality due to 'causal conditions' tendency to fall into coherent patterns (Meyer et al., 1993). In Tables 2, 3 and 4 the associated truth tables are shown, which include logically possible combinations with strong membership to the outcome: VC funding (Table 2), debt financed by banks (Table 3) and government grants financing (Table 4).

Table 2

Truth table for logical configurations when considering $\mathrm{VC}$ funding outcome

\begin{tabular}{c|c|c|c|c|c|c|c}
\hline $\begin{array}{c}\text { The nature } \\
\text { of the } \\
\text { project }\end{array}$ & Market & $\begin{array}{c}\text { Entrepreneurial } \\
\text { orientation }\end{array}$ & Assets & $\begin{array}{c}\text { Management } \\
\text { profile } \\
\text { and skills }\end{array}$ & Number & $\begin{array}{c}\text { VC } \\
\text { funding }\end{array}$ & $\begin{array}{c}\text { Raw } \\
\text { consistency }\end{array}$ \\
\hline 1 & 1 & 1 & 1 & 0 & 15 & 1 & 0.979796 \\
\hline 1 & 0 & 1 & 1 & 1 & 2 & 0 & 0.941660 \\
\hline 1 & 1 & 1 & 0 & 1 & 3 & 0 & 0.935124 \\
\hline 1 & 0 & 1 & 0 & 1 & 6 & 0 & 0.928488 \\
\hline 1 & 1 & 1 & 1 & 0 & 6 & 0 & 0.920169 \\
\hline 1 & 1 & 1 & 0 & 0 & 3 & 0 & 0.920012 \\
\hline 1 & 0 & 1 & 0 & 1 & 5 & 0 & 0.901143 \\
\hline 0 & 0 & 1 & 1 & 0 & 3 & 0 & 0.753874 \\
\hline 1 & 0 & 0 & 1 & 0 & 6 & 0 & 0.740734 \\
\hline 0 & 0 & 1 & 0 & 0 & 4 & 0 & 0.448873 \\
\hline
\end{tabular}

Source: author's own.

Table 3

Truth table for logical configurations when considering debt financed by banks outcome

\begin{tabular}{c|c|c|c|c|c|c|c}
\hline $\begin{array}{c}\text { The nature } \\
\text { of the } \\
\text { project }\end{array}$ & Market & $\begin{array}{c}\text { Entrepreneurial } \\
\text { orientation }\end{array}$ & Assets & $\begin{array}{c}\text { Management } \\
\text { profile } \\
\text { and skills }\end{array}$ & Number & $\begin{array}{c}\text { Debt } \\
\text { financed } \\
\text { by banks }\end{array}$ & $\begin{array}{c}\text { Raw } \\
\text { consistency }\end{array}$ \\
\hline 1 & 1 & 1 & 1 & 0 & 7 & 1 & 0.714847 \\
\hline 1 & 0 & 0 & 1 & 1 & 2 & 1 & 0.652137 \\
\hline 1 & 0 & 1 & 1 & 1 & 4 & 0 & 0.649214 \\
\hline 1 & 1 & 1 & 0 & 0 & 2 & 0 & 0.541834 \\
\hline 0 & 0 & 1 & 1 & 0 & 3 & 0 & 0.440241 \\
\hline 1 & 1 & 1 & 1 & 1 & 14 & 0 & 0.351784 \\
\hline 1 & 1 & 1 & 0 & 1 & 2 & 0 & 0.345414 \\
\hline 1 & 0 & 1 & 0 & 0 & 6 & 0 & 0.319716 \\
\hline 1 & 0 & 1 & 0 & 1 & 7 & 0 & 0.298765 \\
\hline 0 & 0 & 1 & 0 & 0 & 6 & 0 & 0.185232 \\
\hline
\end{tabular}

Source: author's own. 
Table 4

Truth table for logical configurations when considering government grants financing outcome

\begin{tabular}{c|c|c|c|c|c|c|c}
\hline $\begin{array}{c}\text { The nature } \\
\text { of the } \\
\text { project }\end{array}$ & Market & $\begin{array}{c}\text { Entrepreneurial } \\
\text { orientation }\end{array}$ & Assets & $\begin{array}{c}\text { Management } \\
\text { profile } \\
\text { and skills }\end{array}$ & Number & $\begin{array}{c}\text { Government } \\
\text { grants } \\
\text { financing }\end{array}$ & $\begin{array}{c}\text { Raw } \\
\text { consistency }\end{array}$ \\
\hline 0 & 0 & 1 & 0 & 0 & 6 & 1 & 0.816557 \\
\hline 1 & 0 & 1 & 0 & 0 & 7 & 1 & 0.721136 \\
\hline 0 & 0 & 1 & 1 & 0 & 2 & 0 & 0.683663 \\
\hline 1 & 0 & 1 & 0 & 1 & 4 & 0 & 0.591363 \\
\hline 1 & 1 & 1 & 0 & 0 & 3 & 0 & 0.571213 \\
\hline 1 & 1 & 1 & 0 & 1 & 2 & 0 & 0.417261 \\
\hline 1 & 0 & 0 & 1 & 1 & 3 & 0 & 0.297361 \\
\hline 1 & 1 & 1 & 1 & 0 & 6 & 0 & 0.217971 \\
\hline 1 & 0 & 1 & 1 & 1 & 4 & 0 & 0.144545 \\
\hline 1 & 1 & 1 & 1 & 1 & 16 & 0 & 0.099304 \\
\hline
\end{tabular}

Source: author's own.

There are two issues regarding the information in a truth table. Firstly, the identification of which cases are most strongly associated with which configuration is determined by assigning 1 to the degree of membership values $>0.5$, and 0 to those $<0.5$ (hence each case can only be associated to one combination in terms of strong membership). Secondly, the decision of which configurations are considered strongly associated with financing by $\mathrm{VC}$ (ones in the VC funding column in Table 2), debt (ones in the debt financed by banks column in Table 3) and government grants financing (ones in the government grants financing column in Table 4), is based on the consideration of the respective raw consistency columns. The important point to reiterate here is that the rows in each truth table, in Tables 2 to 4, are not specifically representing individual cases, but the logical configurations for which they were strongly associated in each single case (with five conditions considered there are $2^{5}=32$ logical configurations, in Tables 2, 3 and 4 the same ten logical configurations are shown, for which at least one case is strongly associated with it).

The raw consistency measures the proportion of memberships in the outcome explained by each logical configuration, and is computed for each logical configuration from the degree of membership data by dividing the sum of consistent membership in the logical configuration by the sum of membership in the outcome (see Ragin, 2008). The choice of a threshold value for this raw consistency variable to effect those configurations considered strongly associated with a respective outcome impacts on the degree of evidence used to identify the necessary and sufficient conditions (Ragin, 2006). 
Next, the causal conditions most strongly linked with the VC funding, debt financed by banks and government grants financing outcomes were considered. This fundamentally comes down to seeing what combinations of causes discern those configurations, as per Tables 3, 4 and 5. Prior to this, consideration has to be given to those configurations which are not included in the respective truth table (in Tables 2, 3 and 4). These are configurations that are theoretically plausible, but not empirically present. The inclusion or exclusion of remainders in set-theoretic analyses is a contentious issue. The inclusion of the remainders in the analysis, by considering their association with the absence of the outcome, leads to what is called the 'complex' solution. An alternative is to exclude the remainders from the analysis; this is termed the 'parsimonious' solution. Between these, there is the 'guided by theory' solution, which attempts to assign the outcome to logical remainders, termed the intermediate solution (see Ragin, Sonnett, 2004; Ragin, 2008). Importantly, the different treatments of these logical remainders lead to different solution formulas (Ragin, 2008). However, all formulas are logically true because they do not contradict the available empirical information contained in the truth table.

\section{RESULTS}

The parsimonious and intermediate solutions were presented and analyzed. The results from the parsimonious and intermediate solutions can be summarized using a configuration chart - Table 5 (). Utilizing the notation system from Ragin and Fiss (2008), each column in Table 4 represents a configuration of conditions linked to the respective outcomes. Full circles $(\Theta)$ indicate the presence of a condition, while barred circles $(\ominus)$ indicate a condition's absence. Furthermore, core and complementary conditions are distinguished by the symbols' size: larger circles indicate core conditions that are part of parsimonious solutions. Smaller circles indicate complementary conditions that only occur in intermediate solutions. Each panel represents the alternative causal combinations or recipes for the outcome (Ragin, 2008). These are consecutively numbered S1, S2, etc.

In brief, consistency measures the degree to which cases sharing a given condition agree in displaying an outcome. Raw coverage measures the overall coverage of a combination that may overlap with other combinations. Unique coverage refers to coverage uniquely due to a combination. Solution consistency measures the degree to which membership in the solution (the 
set of solution terms) is a subset of membership in the outcome. Lastly, solution coverage refers to the combined coverage of all combinations leading to the outcome (see also Ragin, 2008).

Table 5

Configuration chart (based on Ragin and Fiss, 2008)

\begin{tabular}{|c|c|c|c|c|}
\hline & VC funding & \multicolumn{2}{|c|}{$\begin{array}{l}\text { Debt financed } \\
\text { by banks }\end{array}$} & $\begin{array}{l}\text { Government } \\
\text { grants } \\
\text { financing }\end{array}$ \\
\hline Conditions & $\mathrm{S} 1$ & $\mathrm{~S} 2$ & S3 & S4 \\
\hline The nature of the project & & $\bullet$ & & 0 \\
\hline Market & $\bullet$ & & O & $\theta$ \\
\hline Entrepreneurial orientation & & & ○ & $\bullet$ \\
\hline \multicolumn{5}{|l|}{ Assets } \\
\hline Management profile and skills & $\ominus$ & $\bullet$ & & \\
\hline Consistency & 0.982847 & 0.750117 & 0.756649 & 0.783345 \\
\hline Raw coverage & 0.389152 & 0.278877 & 0.376547 & 0.432543 \\
\hline Unique coverage & 0.157320 & 0.104337 & 0.221677 & 0.426544 \\
\hline Solution consistency & 0.951532 & \multicolumn{2}{|c|}{0.929486} & 0.943653 \\
\hline Solution coverage & 0.556778 & \multicolumn{2}{|c|}{0.388513} & 0.447895 \\
\hline
\end{tabular}

Source: author's own.

Fiss (2011) argues that it is important to distinguish between the core and peripheral configurations of causal conditions in a set-theoretic analysis, especially those pertaining to the derivation of organizational configurations. According to him, core configurations are those 'causal conditions for which the evidence indicates a strong causal relationship with the outcome of interest' (Fiss, 2011). By contrast, those causal conditions for which the causal relationship is weaker can be regarded as peripheral configurations.

Configurations of management profile and skills, entrepreneurial orientation, the nature of the project, assets and market leading to VC funding

Table 5 indicates that there are three core conditions associated with VC funding - solution S1, namely management profile and skills, entrepreneurial orientation, the nature of the project. In terms of peripheral conditions 
associated with VC funding, the table suggests that the core conditions are complemented by market characteristics - the size and international scope. Therefore, this group has included firms for which the founders team, in spite of their high technological skills and considerable experience in a given scientific discipline, has low managerial skills. Those results can be related with the existing literature on the determinants for venture capital to back a high-tech firm. Initial qualitative studies analysing the venture capitalists' preferences (Muzyka, Birley, Leleux 1996; Shepherd, Ettenson, Crouch 2000) have found that they prefer to finance those founders with higher skills. On the other hand, papers analysing the entrepreneurs' preferences (Giudici, Paleari 2000) confirm the suggestions of the pecking-order argument, according to which entrepreneurs prefer to preserve decisionmaking control and ownership, so they will look for venture capital only when it is needed. From the complementary assets theory (Teece, 1986), some authors suggest that new technology-based firms need venture capital in the case of a lack of managerial skills. In fact, with data at a firm level, empirical studies have found evidence that founders with less managerial skills have a greater likelihood of receiving venture capital funds (Shane, Stuart, 2002; Heirman, Clarysse, 2004; Clarysse, Knockaert, Lockett, 2007). On the other hand, the entrepreneurs were characterized by a high tendency to entrepreneurial risk with a low stigma of failure. This confirms the existing literature asserting that entrepreneurs with a low stigma of failure run more aggressive businesses and are more likely to obtain equity finance (Minola, Giorgino, 2008). Moreover, this group includes firms having innovative technologies, manufacturing technologically advanced products and possessing a considerable number of patents and licences. Therefore this confirms the assumptions in the existing literature that IP protection is greater among those firms that have received venture capital. Regarding the degree of IP protection, Ortin-Angel and Vendrell-Herrero (2010) observe that in those firms with a higher number of patents, licences and their own brands there is a greater and statistically significant presence of venture capitalists. What is more, high information asymmetries also occurred here, especially in the low value of securities, as well as the high growth and high risk of the project, which, according to the literature (Ueda, 2004) also leads entrepreneurs to financing through a venture capitalist. In addition, the group included firms functioning in the international and global markets, which too, as reported by literature (Heirman, Clarysse, 2004), has influence on obtaining $\mathrm{VC}$ financing. 
Configurations of management profile and skills, entrepreneurial orientation, the nature of the project, assets and market leading to debt financed by banks

The results presented in Table 5 highlight that there is a single core condition associated with debt financed by banks, namely the high value of any types of guarantees which are provided by the entrepreneur. This fact has its justification in the literature, and any assets of a firm are often the main determinant for banks when releasing financial resources (Chittenden et al., 1996). This condition occurs in each of the two solutions obtained from the analysis (S2 and S3). Regarding the peripheral conditions associated with debt financed by banks, Table 5 illustrates that for $S 2$, the presence of a high value of possessed guarantees and securities is complemented on the part of the entrepreneur part (or an entrepreneurial team) with high managerial and technological skills and considerable professional experience and also the nature of the project. In turn, in the case of solution S3, the obtaining of debt financed by banks was associated with the tendency to undertake projects with a high risk complemented by market characteristics - the size and international scope. This shows that the bank system might be open to original and slightly more risky evaluations, considering, for example, human capital as innovative securities for the loan (Minola, Giorgino, 2008).

Configurations of management profile and skills, entrepreneurial orientation, the nature of the project, assets and market leading to government grants financing (financing through grants)

The results in Table 5 show that there is one core condition associated with government grants financing - solution S4, namely the nature of the project. In terms of peripheral conditions associated with government grants financing, the QCA suggest that the core condition is complemented by entrepreneurial orientation and market characteristics - the size and scope. This group has included enterprises, whose founding team is characterized by high tendencies to entrepreneurial risk. The main motivation for esta-blishing and developing firms was self-employment, self-guiding in the identification, taking and using chances and willingness to act indepen-dently. The firms have innovative technologies and manufacture technologically advanced products, however, to the domestic market.

\section{CONCLUSIONS}

For many years, the issue of establishing and financing start-ups has been one of the central points of the policy of the European Union and national governments in the area of entrepreneurship. Increasing the number of newly 
established firms by facilitating the access to capital and funding and reducing the regulatory burdens has been perceived as an important factor contributing to enhancing the innovativeness of national economies and stabilizing the labour markets. Europe-wide initiatives and activities, such as the Risk Capital Action Plan, the Financial Services Action Plan, JEREMIE (Joint European Resources for Small and Medium Sized Enterprises), the European Venture Capital Association (EVCA) and the European Investment Fund are milestones in building the infrastructure of the financial support for entrepreneurship. The advances made in building the environment favouring entrepreneurship are huge, however further activities are needed as the population of start-ups is becoming increasingly diversified and demanding. New businesses, especially those originating from the academic world, require a completely different approach than other start-ups.

The constraints which the need for external capital puts on the development of a high-tech ecosystem is strongly debated in the fields of economics and management science. This paper provides some answers to the questions that arise about the financial strategy of USOs and - most importantly whether the variables affecting the financial decisions of USOs can be focused and form separate, different and even new alternative combinations.

A systematic revision of the literature suggested us to take a multidimensional approach, considering the figure of the entrepreneur, the nature of the project, the presence of particular financial constraints and guarantees, and the nature of the market. This study, by using QCA, sought to improve our understanding of the creation of the financial strategy of USOs by investigating the following main issues. Firstly, it shows how bundles of attributes such as the entrepreneurial figure, the nature of the project, the presence of particular financial constraints and guarantees, and the market characteristics, are configured in the area of the financing of USOs in Poland. Secondly, it enables the examination of how these configurations are associated with the outcomes of $\mathrm{VC}$ funding, debt financed by banks and government grants financing. This analysis has identified four alternative causal combinations associated with the entrepreneurial figure, the nature of the project, the presence of particular financial constraints and guarantees, and the market characteristics; one of them leads to VC funding, the next alternative two to debt financed by banks and the last ones to government grants financing outcomes.

At the same time, this paper offered one of the first set-theoretical analyses of the configurations of determinants creating the financial strategy of USOs. In this instance, the results of analyses suggest that the presence of 
entrepreneurial orientation and an innovative project with strong IP protection and a low stigma of failure with high management skills, are strongly associated with VC funding in Polish USOs. The high value of any types of guarantees is strongly associated with debt financed by banks, and the nature of the project complemented by entrepreneurial orientation are strongly associated with government grants financing.

The use of QCA is an original contribution to the wide range of determinant analysis in entrepreneurial finance. Achieving the goal - to demonstrate the existence of alternative sets of determinants creating a financial strategy - helps an entrepreneur wanting to start up a firm, identifies the best financer, banker, or venture capitalist for his/her project. The carried out research can be used as a starting point for the future creation of tools to guide entrepreneurs in start-ups, who are challenged by the choice of the financial strategy.

The next step should be to extend the research validation to a greater number of cases (while keeping the qualitative and in-depth approach) and extend the empirical evidence through a wide quantitative analysis that will give statistical consistency to the research and may permit a generalization. It can be concluded that fsQCA offers a powerful means for theorizing and testing for the presence of complex configurations of attributes in entrepreneurial organizations.

\section{REFERENCES}

Audretsch, D. B., Lehmann, E. E., Financing high-tech growth: the role of bank and venture capitalists, "Schmalenbach Business Review", 56(4), pp. 340-357, 2004.

Callan, B., Generating spin-offs: evidence from across the OECD, "Science Technology Industry Review, Special Issue on Fostering High Tech Spin-Offs: A Public Strategy for Innovation", 26, pp. 13-55, 2001.

Chittenden, F., Hall, G., Hutchinson P., Small firm growth, access to capital markets and financial structure: review of issues and an empirical investigation, "Small Business Economics", 8, pp. 59-67, 1996.

Clark, W., Gilligan, M., Golder, M., A simple multivariate test for asymmetric hypotheses, "Political Analysis", 14, pp. 311-331, 2006.

Clarysse, B., Knockaert, M., Lockett, A., Outside board members in high-tech start-ups, "Small Business Economics", 29, pp. 243-259, 2007.

Cohen, W. M., Levinthal, D. A., Absorptive capacity: a new perspective on learning and innovation, "Administrative Science Quarterly", 35, pp. 128-152, 1990.

Colombo, M. G., Delmastro, M., How effective are technology incubators? Evidence from Italy, "Research Policy", 31, pp. 1103-1122, 2002. 
Colombo, M. G., Grilli, L., Start-up size: the role of external financing, "Economic Letters", 88, pp. 243-250, 2005.

Colombo, M. G., Grilli, L., Piva, E., In search of complementary assets: The determinants of alliance formation of high-tech start-ups, "Research Policy", 35, pp. 1166-1199, 2006.

Covin, J. G., Slevin, D. P., Strategic management of small firms in hostile and benign environments, "Strategic Management Journal", 10, pp. 75-87, 1989.

Cressy, R., Funding gaps: a symposium, "Economic Journal”, 112, pp. 1-16, 2002.

Ensley, M. D., Carland, J. C., Carland, J. W., The effects of entrepreneurial team skill heterogeneity and functional diversity on new venture performance, "Journal of Business and Entrepreneurship", 10(1), pp. 1-11, 1998.

Fiss, P. C., Building better causal theories: A fuzzy set approach to typologies in organization research, "Academy of Management Journal", 54(2), pp. 393-420, 2011.

Giudici, G., Paleari, S., The provision of finance to innovation: A survey conducted among Italian technology-based firms, "Small Business Economics", 14, pp. 37-53, 2000.

Hall, B., The financing of research and development, "Oxford Review of Economic Policy", 18, pp. 35-51, 2002.

Hellmann, T., Puri, M. The interaction between product market and financing strategy: The role of venture capital, "Review of Financial Studies", 13(4), pp. 959-984, 2000.

Heirman, A., Clarysse, B., How and why do research-based start-ups differ at founding? A resource-based configurational perspective, "Journal of Technology Transfer", 29, pp. 247-268, 2004.

Huyghebaert, N., Van de Gucht, L., The determinants of financial structure: new insights from business start-ups, "European Financial Management”, 13(1), pp. 101-133, 2007.

Jung, H., Kim, B. K., Determinant factors of university spin-off: the case of Korea, "The Journal of Technology Transfer", 43(6), pp. 1631-1646, 2018.

Klotz, A. C., Hmieleski, K. M., Bradley, H. B., Busentiz, L. W., New venture teams: A review of the literature and roadmap for future research, "Journal of Management", 40(1), pp. 226-255, 2013.

Kwiotkowska, A., Konfiguracje organizacyjne akademickich przedsiębiorstw odpryskowych, Difin, Warsaw 2015.

Landier, A., Start-Up Financing: from Banks to Venture Capital, The University of Chicago Graduate School of Business, Chicago, IL, 2002.

Lockett, A. Wright, M., Resources, capabilities, risk capital and the creation of university spin-out companies, "Research Policy", 34(7), pp. 1043-1057, 2005.

Lumpkin, G. T., Dess, G. G., Clarifying the entrepreneurial orientation constructs and linking it to performance, "Academy of Management Review", 21(1), pp. 135-172, 1996.

MacMilla, I. C., Siegiel, R., Narasimha, P. N. S., Criteria used by venture capitalists to evaluate new venture proposals, "Journal of Business Venturing", 1, pp. 119-128, 1985.

Mann, R. J., Sager, T. W., Patents, venture capital and software start-ups, "Research Policy", 36, pp. 193-208, 2007.

Miller, D., Freisen, P., Archetypes of organizational transition, “Administrative Science Quarterly”, 25, pp. 268-299, 1980. 
Minola, T., Giorgino, M., Who's going to provide the funding for high tech start-ups? A model for the analysis of determinants with a fuzzy approach, "R\&D Management", 38(3), pp. 335-351, 2008.

Munari, F., Toschi, L., Do venture capitalists have a bias against investment in academic spin-offs? Evidence from the micro and nanotechnology sector in the UK, "Industrial and Corporate Change", 20(2), pp. 397-432, 2010.

Muzyka, C., Birley, S., Leleux, B., Trade-offs in the investment decisions of European venture capitalists, "Journal of Business Venturing", 11, pp. 273-87, 1996.

Ndonzuau, F. N., Pirnay, F., Surlemont, S., A stage model of academic spin-off creation, "Technovation", 22, pp. 281-289, 2002.

Ortin-Angel, P., Vendrell-Herrero, F., Why do university spin-offs attract more venture capitalists?, "Venture Capital", 12(4), pp. 285-306, 2010.

Polish Entrepreneurship Development Agency, The research report on the state of small and medium-sized companies in Poland, Warsaw, 1-91, 2018.

Pattnaik, P. N., Pandey, S. C., University Spinoffs: What, Why, and How?, "Technology Innovation Management Review", 4(12), pp. 44-50, 2014.

Quince, T., Whittaker, H., Entrepreneurial orientation and entrepreneurs' intentions and objectives, Economic and Social Research Centre (ESRC) for Business Research, University of Cambridge Working Paper No. 271, 2003.

Ragin, C. C., The comparative method: Moving beyond qualitative and quantitative strategies, Berkeley: University of California Press, 1987.

Ragin, C. C., Constructing Social Research. Pine Forge Press: A Sage Publications Company, Thousand Oaks, CA, 1994.

Ragin, C. C., Fuzzy-Set Social Science. The University of Chicago Press, Chicago and London 2000.

Ragin, C. C., Set relations in social research: evaluating their consistency and coverage, "Political Analysis", 14, pp. 291-310, 2006.

Ragin, C. C., Redesigning social inquiry: Fuzzy sets and beyond, Chicago: University of Chicago Press, 2008.

Ragin, C. C., Fiss, P., Net effects versus configurations: an empirical demonstration, [in:] Ragin, C. C. (eds..), Redesigning Social Inquiry, 1, pp. 190-212. University of Chicago Press, Chicago and London 2008.

Ragin, C. C., Sonnett, J., Between complexity and parsimony: limited diversity, counterfactual cases, and comparative analysis, UCLA: Department of Sociology, UCLA, 2004. Retrieved from https://escholarship.org/uc/item/1zf567tt.

Roberts, E. B., Entrepreneurs in high technology, lessons from MIT and beyond. Oxford University Press, New York 1991.

Schäfer, D., Werwatz, A., Zimmermann, W., The determinants of debt and private-equity financing in young innovative SMEs: evidence from Germany, "Industry and Innovation", 11, pp. 225-248, 2003.

Shane, S., Academic entrepreneurship. University spin-offs and wealth creation. Edward Elgar, Cheltenham, UK, 2004. 
Shane, S., Cable, D., Network ties, reputation, and the financing of new ventures, "Management Science", 48(3), pp. 364-381, 2002.

Shane, S., Khurana, R., Bringing individuals back in: The effects of career experience and new firm founding, "Industrial and Corporate Change", 12( )3, pp. 519-543, 2003.

Shane, S., Stuart, T., Organizational endowments and the performance of university start-up, "Management Science", 48(1), pp. 154-170, 2002.

Shepherd, D. A., Ettenson, R., Crouch, A., New venture strategy and profitability: A venture capitalist's assessment, "Journal of Business Venturing", 15, pp. 449-467, 2000.

Siegel, D., Waldman, D., Link, A., Assessing the impact of organizational practices on the relative productivity of university technology transfer offices: An exploratory study, "Research Policy", 32, pp. 27-48, 2003.

Teece, D. J., Profiting from technological innovation: Implications for technological integration, collaboration, licensing and public policy, "Research Policy", 15, pp. 285305, 1986.

Ucbasaran, D., Lockett, A., Wright, M., Westhead, P., Entrepreneurial founder teams: Factors associated with members entry and exit, "Entrepreneurship Theory and Practice", 28(2), pp. 107-128, 2003.

Law on Higher Education of July 27, 2005, “Journal of Laws” No. 164, item 1365, dated 30 August 2005, as amended).

Van de Ven, A. H., Hudson, R., Schroder, D. M., Designing new business start-ups entrepreneurial organizational and ecological considerations, "Journal of Management", 10, pp. 87-107, 1984.

Vohora, A., Wright, M., Lockett, A., Critical junctures in the growth in university high-tech spinout companies, "Research Policy", 33, pp. 147-175, 2004.

Wallmeroth, J., Wirtz, P., Groh, A. P., Venture Capital, Angel Financing, and Crowdfunding of Entrepreneurial Ventures: A Literature Review, "Foundations and Trends in Entrepreneurship", 14 (1), pp. 1-129, 2018.

Wright, M., Clarysse, B., Mustar, P., Lockett, A., Academic entrepreneurship in Europe. Edward Elgar, Cheltenham, UK, 2007.

Wright, M., Lockett, A., Clarysse, B., Binks, M., University spin-out companies and venture capital, "Research Policy", 35(4), pp. 481-501, 2006.

Received: November 2017, revised: March 2019 